\title{
REFUGEES, MIGRANTS AND STATELESS PERSONS IN INTERNATIONAL LAW - REVIEW OF LEGAL ACTS
}

\author{
Tomasz Słapczyński \\ Maria Curie-Skłodowska University in Lublin \\ Faculty of Political Science, PhD student \\ e-mail: tslapczynski@gmail.com
}

\begin{abstract}
The paper constitutes an attempt to describe the refugee issue as a very important problem in international law. Problem which can bring both profits and losses for involved countries in many areas. Along with the inflow of people from abroad, initial expenses related to the administrative process increase. At the same time, the increase in human capital can also be noted. It depends on the policy of a given country, whether it can effectively use human capital or only social costs for the country are generated. Sometimes international law obligation is not enough to convince society that accepting refugees is a right and good decision. The paper focuses on how and with which legislation tools it is done and explores whether or not it is effective. The paper consists, among others, of the following sections: "Who is refugee - legal description", "Non-governmental organizations", "International administration - UNHCR", "EU administration created to help refugees", "The Treaty of Lisbon and refugee policy". In those subchapters, the legal basis of the refugee protection system in the Western world as well as the refugee policy and execution of this law are discussed.
\end{abstract}

Keywords: refugees, international law, migration, international organizations, UN

\section{WHO IS REFUGEE - LEGAL DESCRIPTION, INTERNATIONAL CONDITIONS}

The phenomenon of emigration and exile is directly related to the globalization process. According to Marek Pietraś, globalization process is generally identified with the analysis of structure changes, most of all, with the functioning of the international community. The qualitative changes involve the revaluation of the dominant model of the functioning of human society, considering distinction between national and international conditions. About seven dimensions of globalization are mentioned: technology, communication, environment, economic, organization of labor, culture and civic society [Pietraś 2002: 35-36, 44]. 
The definition of refugees by UN Agency [United Nations Organization, http://www.un.org/en/index.html] says that they are "persons who are outside their country of origin for reasons of feared persecution, conflict, generalized violence, or other circumstances that have seriously disturbed public order and, as a result, require international protection" [Goodwin-Gill, McAdam 2007: 7-13]. Early scientists, who are interested in the refugee issue, were focused on the Geneva Convention (1929) and its history, especially Paul Weis [1995], Nehemiah Robinson [1953] and Atle Grahl-Madsen [1972]. Today, refugee protection is governed by a combination of international law, human rights, regional agreements and national laws. The actors include single persons, states, international organizations, non-governmental organizations (NGOs), companies and smugglers [Goodwin-Gill, McAdam 2007: 5-8]. The term "nationality", according to the Geneva Convention, also refers to the ethnic or linguistic group. Persecution against this background may consist in a hostile attitude towards such minorities. The term "specific social group" usually includes people of similar origin, customs or social status. In addition, the fear of persecution for this reason often combines with the fear of persecution for other reasons, such as race or religion. To sum up, the fear of persecution must be justified and because of this fear, the person cannot or does not want to take advantage of the protection offered by his country of origin, to be able to obtain refugee status. This inability may be caused by civil war, riots or refusal of the state to provide protection to such a person. The third condition mentioned above is the lack of exclusion clauses relating to the person applying for the refugee status [Kowalczyk 2014: 214-217].

This refugee definition can be found in the 1951 UN Convention, and regional refugee instruments also in UNHCR's (The UN Refugee Agency) statute. As it was mentioned above, refugees are a specifically defined and protected group in international law. They cross national borders to look for safety in nearby countries and become internationally recognized as refugees with access to assistance from states, UNHCR, and particular organizations. It is dangerous for them to return home. If they are refused the asylum, they can meet deadly consequences. Article 14 of the Universal Declaration of Human Rights states that everyone has the right to seek and enjoy asylum. However, the definition was incomprehensible and did not provide clear content. The provisions of the 1951 Convention, include the basic international norm in respect of which all measures for the protection and treatment of refugees are assessed. According to this principle, refugees cannot be expelled or returned to situations in which their life or freedom would be threatened. States bear the primary responsibility for this protection. UNHCR works closely with governments, helping them and assisting with solving the problem. The 1951 Convention and its 1967 Protocol were a legal base to save millions of lives but this law is not perfect and sometimes fails [http://www.unhcr.org/ en-us/news/latest/2016/3/56e95c676/refugees-migrants-frequently-asked-questions-faqs.html]. 
The Fourth Geneva Convention protects civilians, including those in occupied territories. It referred to combatants only and not to civilians. The events of World War II showed the disastrous consequences of the lack of convention for the protection of civilians. The Convention adopted in 1949 takes account of the experiences of World War II. It contains a short section concerning the general protection of civilians in war. It was very important for civilians in occupied territories [https://www.icrc.org/eng/war-and-law/treaties-customary-law/geneva-conventions/overview-geneva-conventions.htm]. Geneva Convention Relative to the Protection of Civilian Persons in Time of War of 12 August 1949 includes in part III - Status and Treatment of Protected Persons, in section II - Aliens in the Territory of a Party to the Conflict in Article 44, chapter VII named "Refugees". Article 44 says that "In applying the measures of control mentioned in the present Convention, the Detaining Power shall not treat as enemy aliens exclusively on the basis of their nationality de jure of an enemy State, refugees who do not, in fact, enjoy the protection of any government" [Geneva Convention Relative to the Protection of Civilian Persons in Time of War of 12 August 1949, part III - Status and Treatment of Protected Persons, section II - Aliens in the Territory of a Party to the Conflict. Article 44, Chapter VII. "Refugees"].

Another, very important notion connected with migration is "migrant". There is no legal and universal definition but some international organizations, media and authorities create, understand and use this word. Migrants are persons who seek for better life conditions in another place, but they have no feeling of belonging to the homeland. The Convention provides that "We need to ensure that the human rights of migrants are respected. At the same time, we also need to provide an appropriate legal and operational response for refugees, because of their particular predicament and to avoid diluting state responsibilities towards them" [Geneva Convention...]. Therefore, UNHCR always refers to "refugees" and "migrants" separately, to provide clarity about the causes and character of refugee movements. This is necessary because of obligations owed to refugees under international law. The factors leading people to move can be complex. Often the causes are multi-faceted. Migrants may move to improve their lives by finding work or in some cases for education, family reunion, or other reasons. People who leave their countries for these reasons would not usually be considered refugees under international law. Another significant difference between migrants and refugees is that migrants are protected by international human rights law, which is connected with people's protection in general. The human rights constitute a fundamental aspect, especially for migrants. Another term connected with people movement is "forced migration". This terms is sometimes used by social scientists as a general term, which describes many kinds of movement, both across international borders and inside a single country. In the past, the term has been used to refer to people, who have been displaced by environmental disasters, conflict or development projects. "Forced migration" is not a legal definition [http://www.unhcr.org/en-us/news/latest/2016/3/56e95c676/ refugees-migrants-frequently-asked-questions-faqs.html]. 
As for asylum seekers, we can also describe them as people who "have sought international protection and whose claims for refugee status have not yet been determined, irrespective of when they may have been lodged". Internally displaced persons (IDPs), on the other hand, are people or groups of individuals who

have been forced to leave their homes or places of habitual residence, in particular as a result of, or in order to avoid the effects of armed conflict, situations of generalized violence, violations of human rights, or natural or man-made disasters, and who have not crossed an international border. For the purposes of UNHCR's statistics, this population only includes conflict-generated IDPs to whom the Office extends protection and/or assistance [http://popstats.unhcr.org/en/overview].

In case of "returned refugees", the definition reads as follows: "Returned refugees are former refugees who have returned to their country of origin spontaneously or in an organized fashion but are yet to be fully integrated. Such return would normally only take place in conditions of safety and dignity". "Stateless persons", in turn,

are defined under international law as persons who are not considered as nationals by any State under the operation of its law. In other words, they do not possess the nationality of any State. UNHCR statistics refer to persons who fall under the agency's statelessness mandate because they are stateless according to this international definition, but data from some countries may also include persons with undetermined nationality [http:// popstats.unhcr.org/en/overview].

The data shown by UNHCR in 2017 shows the highest levels of displacement on record. About 65.6 million people around the world have been forced from home. Among them there are nearly 22.5 million refugees, half of them are under the age of 18. There are also about 10 million stateless people who have been denied a nationality and access to basic rights like education, healthcare, employment and freedom of movement. In 2017, nearly 20 people are forcibly displaced every minute as a result of conflict or persecution. This statistics shows that there is much work to be done to help people in need. The main reason for the movement of refugees is mostly armed conflicts in the world, political crises as well as undemocratic governments. Those data were gathered by full-time statisticians in UNHCR's Field Information and Coordination Section. They track the number of people forced to escape when a major displacement crisis erupts. Owing to this, it is possible to predict how many people need help. Staff of the Information and Coordination Section employs 10,966 workers, around $87 \%$ are working in the field. They work in 130 countries, with staff based in a mixture of regional and branch offices and sub and field offices. They work to help the displaced, specializing in a wide range of disciplines, including legal protection, administration, community services, public affairs and health. These aid actions are funded by voluntary contributions, with $87 \%$ from governments and the European Union. Three percent comes from other inter-governmental organizations and pooled funding mechanisms, while a further 
$9 \%$ is from the private sector, including foundations, corporations and the public. Additionally, they receive a limited subsidy from the UN budget for administrative costs, and accept in-kind contributions, including items such as tents, medicines and trucks. UNHCR was launched on an annual budget of US\$300,000 in 1950. Its annual budget rose to more than US\$ 1 billion in the early 1990s and reached a new annual high of US\$ 7.7 billion in 2017. UNHCR's programme supports continuing operations and supplementary programme to cover emergencies, for example, the Syria crisis. The Section's workers claim that the budget is not big enough, but it is still a lot, and another problem is that a lot of cost are created by administration. Data resource are used by all partners to respond to the needs of refugee populations. UNHCR's Statistics Database

\begin{abstract}
provides data, reports and other information essential for field operations. It also carries statistical reports on people of concern - refugees, asylum seekers, returned refugees, the internally displaced and stateless people. Detailed information on country of asylum, place of origin, gender, age, location and legal status of refugees is available [http://www. unhcr.org/figures-at-a-glance.html].
\end{abstract}

\title{
INTERNATIONAL ADMINISTRATION - UNHCR
}

The basic regulation, as was mentioned at the beginning, is an agreement and adoption of the text of the Geneva Convention preceded by the reception on December 14, 1950, by the UN General Assembly, of the Statute of the Office of the United Nations High Commissioner for Refugees. The UN had a three-year mandate for the implementation of specific tasks. It was prolonged many times. The UN General Assembly abolished the requirement to renew the mandate every few years. The statute specifies the basic functions and tasks of the High Commissioner and the organization of the Office. The High Commissioner is responsible for the management and supervision of UNHCR offices. He directs the work of the agenda with the help of Deputy High. The catalog of EU administration tasks is broad and usually defined in a non-exhaustive way. The UNHCR structure also includes regional offices, representative offices, branches and regional offices. UNHCR's activities in individual countries are directed by Representatives of High Commissioner. There are also Regional Representatives of the High Commissioner, who are responsible for coordinating activities in a specific region, including several countries (e.g., Central Europe). From 1959, the Commissioner has been assisted by advisory body, namely the Executive Committee of the Office of the United Nations High Commissioner for Refugees Affairs. The Office of the UN High Commissioner for Refugees is directly involved in protection of refugees. They are involved in various activities in the main areas related to finding a permanent solution to the problem. Resettlements, integration in the host country and voluntary returns of refugees. They also cooperate with various entities: states, international, regional, and non-governmental organiza- 
tions. The High Commissioner has control competences in the application of the Geneva Convention, which gives a wide range of powers: consultations on draft acts, issuing soft law acts after legally guaranteed participation in an individual procedure granting refugees status. UNHCR is entitled to take various activities listed in paragraph 8 of the Statute. The High Commissioner shall provide for the protection of refugees by: a) concluding and ratifying international conventions for the protection of refugees, supervising their implementation, b) promoting special agreements calculated to improve the situation of refugees and to limit their number, c) information activities and cooperation with governments. Pursuant to paragraph 6 of the Statute, the powers of the High Commissioner fall under the so-called historical refugees and mandatory refugees. The UN has expanded the UNHCR's mandate and the responsibilities of this organization by obliging to protect different groups of people not covered by the provisions of binding international acts. The acts established in 1957 by the Committee have a similar effect. The term "internal refugee" is in practice applied to people who were forced to leave their country of origin due to civil war or natural disasters, as well as people who left their place of residence, but still remain in the territory of a country.

\section{EU ADMINISTRATION CREATED TO HELP REFUGEES}

The wide definition of administration, which is to ensure the implementation of law and the implementation of policies adopted at the EU level, is defined as a set of various institutions and bodies, consisting of national and EU components [Dyl et al. 2011: 558-668]. Thus, one can speak about two general principles characterizing the administration: separateness and cooperation. The principle of separateness defines the structure of the European administrative order, and the principle of cooperation - its functional aspect. Another act which protects refugees is also provided by regional government organizations. One of the first regional organizations undertaking activities for refugees and regulating their legal situation is the Council of Europe established in 1949. The issue of refugees appeared on the forum of this organization already at the first session of the Parliamentary Assembly in 1949. It is worth mentioning that the Council of Europe was the only European organization that undertook initiatives for the harmonization of asylum policies and practices until the mid-1970s. Almost all major regional organizations have emerged specialized institutions dealing with the problem of refugees. The Council of Europe established [https:/www.coe.int/en/web/portal/-/council-of-europe-action-plan-on-protectingrefugee-and-migrant-children-and-high-level-meetings]:

- Ministerial Conference on Migration - these meetings serve developing direct contacts between interested ministers from Member States and the development of the organization's direction in the period of next 2-3 years.

- Committee of Migration, Refugees and Demography of the Parliamentary Assembly (Committee of Migration, Refugees and Demography) - the 
Committee presents reports, which serve as a basis for adoption by the Parliamentary Assembly resolutions and recommendations, and organizes thematic meetings for representatives of Council of Europe members.

- The European Committee of Migration (CDMG) is the main intergovernmental body responsible for migration issues, including refugees. The Committee conducts research, implements special programs, organizes conferences. It is responsible for preparing meetings of ministers responsible for migrations.

- Ad hoc Committee of Experts on Legal Aspects of Territorial Asylum, Refugees and Stateless Persons (CAHAR) - it has important legislative functions, preparing draft legal acts (resolutions and conventions) submitted then to the Committee of Ministers of the Council of Europe.

Partially, organs of the European Union and the Council of Europe created a large program of helping refugees from the Middle East and African countries. The program was created in order to implement it in all European Union countries but after the "crisis", some countries refused to accept refugees and to participate in the program, which shook the common policy. Another important fact was that most of so-called first-contact countries, e.g., Italy or Greece, were not prepared to handle with the enormous number of refugees. Most of the refugees want to live in reach West European countries which can provide them with social/financial assistance. Among such countries one can mention Germany or France, whereas new countries such as Poland, Hungary, or Bulgaria do not want to help refugees mainly for economic or safety reasons. An important issue in this aspect is international security. It refers to the state security and security of other participants of international relations, as well as to the way of organizing and functioning of the security environment [Pietraś 2006: 324-325]. In many EU countries, the influx of refugees into the European Union is perceived as a sign of crisis. According to Piotr Tosiek, the first cause of the crisis in the European Union is the basic features of the decision-making system, the second reason is the impact of subsequent waves of crisis on the system, the third one is the adaptive capacity of the system [Tosiek 2014: 425]. What is more, the crisis can be a cyclical phenomenon [Podraza 2014: 439].

In addition, the European Commission aims to harmonize legal provisions and practices in the member states in the field of asylum policy. It also gathers information on the influx of refugees to particular states. Twice a year, member states organize meetings of representatives of states with the objective of achieving a common position on refugee issues and justice in respect of fundamental rights and the various legal systems and traditions of the Member States. Additionally, the context of these provisions should be interpreted, in particular with regard to the depth of interference of EU regulation into the member states legislation. Although the measures are aimed at reaching a "common policy" in the field of asylum, based on solidarity between member states and fair to third-country nationals, it must be remembered that matters in the area of freedom, security and 
justice are shared competences with the member states (Article 4 (2) (j) (Treaty on the Functioning of the European Union, TFEU)) and must be implemented in accordance with the principles of subsidiarity and proportionality. In relation to the wording of the TEC after the Amsterdam reform, significant changes are visible in the current Treaty bases. Article 78, paragraph 1 of TFEU stresses the desire to pursue a common policy in the field of asylum, subsidiary protection and temporary protection, the aim of which is to grant an appropriate status to every third-country national who requires international protection. The obligation to comply with the principle of non-refoulement gained the nature of an obligation under the Treaty, not only from international obligations of states or customary law. Moreover, this principle of refugee law covers all forms of protection, and not only the status regulated by the Geneva Convention. The Convention will continue to form the basis and pattern of compatibility of the common Union policy. In addition, Article 78, paragraph 1 refers to "other relevant treaties", among which the European Convention, the Convention against Torture of 1984 and the Convention on the Rights of the Child of 1989, are mentioned. Adoption of secondary law instruments in this field respects the so understood international refugee law, which, at the same time, sets limits for EU regulations. "Any instrument of secondary law which is contrary to the aforementioned treaties does not fulfill the condition of its proper adoption and should be considered to be contrary to primary law". The subjective scope of Treaty regulation includes, as previously, "third country nationals", i.e. persons who are not citizens of the Union within the meaning of Article 20, paragraph 1 of TFEU. For the purposes of Title V of TFEU, stateless persons were razed to them. Citizens of EU member states may enjoy protection in other member states only in accordance with the principles provided for in the Protocol on the right of asylum for citizens of the member states of the European Union, attached to the EC Treaty, and now to the TFEU.

According to the United Nations High Commissioner for Refugees, "the number of refugees and internally displaced persons has reached the highest level since the Second World War in 2015 with over 60 million refugees" [https://www. raptim.org/focus-on-ngos-27-organizations-that-help-refugees/]. A large percentage of them flee from Syria. Almost 11 million Syrians have left their homes since the outbreak of war in March 2011. Now, in the sixth year of the war, about 13.5 million need humanitarian aid inside the country [http://www.unhcr.org/non-governmental-organizations.html; https://www.raptim.org/focus-on-ngos-27-organizations-that-help-refugees/].

The structure of the administration involved in foreigners' protection is multi-leveled and complicated. For example, the EU administration specialized in matters of asylum was developing gradually, in order to support and coordinate the activities of EU member states. The main reason for its existence is monitoring of progress in implementing law. As for the administration bodies at the international level, they are created by the UN High Commissioner for Refugees. Formal international organizations belong to the global administration and sometimes they ex- 
ecute certain tasks both at administrative and non-administrative levels. Between authorities there are different legal dependencies, mainly of a functional nature, covering such aspects as cooperation, coordination, control and supervision.

\section{THE TREATY OF LISBON AND REFUGEE POLICY}

At its meeting in Brussels on 17-18 June 2004, the European Council expressed its conviction that it was time to start the next stage in the process of creating an "area of freedom, security and justice" and obliged the Commission to prepare proposals for a new program for the coming years. Already in 2000, the Commission drew attention to the fact that such an ambitious program, which is the construction of the second stage of Common European Asylum System (CEAS), cannot be implemented on the basis of Article 63 of Treaty of the European Community. The legal basis for the second stage was to become the new Constitutional Treaty. Finally, the activities undertaken to build the next, second stage of CEAS (completion was planned for the end of 2012) are based on the Treaty on the Functioning of the European Union (TFEU). The political assumptions of the second stage were included in the Hague Programme of 2004, the European Pact on Immigration and Asylum, adopted by the European Council on 17 October 2008 and the Stockholm Programme of 2009. The legal basis is Article 78 of TFEU. It is included in Chapter 2 ("Policies on Border Checks, Asylum and Immigration") of Title V ("Area of Freedom, Security and Justice") of Part Three of the TFEU. It is an extension of Article 67 of TFEU, stating that the Union is an area of freedom and security. In the light of the Treaty (and the political documents mentioned), the EU's overall policy on the creation of CEAS now has two dimensions. The first - internal - boils down to further harmonizing the laws of the member states in the field of asylum and joint cooperation between states. As regards the scope of harmonized law in the internal dimension of CEAS, it should be stated that it encompasses competence, material law and procedural matter. In these areas, the Union now has the basis to harmonize national law at its chosen level, it is not limited - as before - to setting minimum standards. Authorizations to take legislative action are included in Article 78, paragraph 2, points a-f of TFEU:

The European Parliament and the Council, acting in accordance with the ordinary legislative procedure, adopt measures concerning the Common European Asylum System covering: (a) a uniform status of asylum for third-country nationals, valid throughout the Union; (b) a uniform status of subsidiary protection for third-country nationals who, without being granted European asylum, need international protection; (c) a common system of temporary protection for displaced persons, in the event of a massive inflow; (d) common procedures for granting and withdrawing uniform asylum or subsidiary protection status; (e) criteria and mechanisms for determining the Member State responsible 
for examining a request for asylum or subsidiary protection; (f) standards concerning the conditions for the reception of applicants for asylum or subsidiary protection.

As pointed out by Steve Peers, despite the use of the word "common", "uniform" in the TFEU, the Union is not obliged to fully harmonize the law in the field of asylum. These provisions should be interpreted in such a way that the EU institutions still have the option (no longer obliged) to continue the harmonization of the law at the level of minimum standards, although in this context the possibility of determining more favorable regulations by the state becomes another [Peers 2011: 308-309].

\section{NON-GOVERNMENTAL ORGANIZATIONS (NGOs)}

As mentioned before, there is a lot of international organizations, especially non-governmental ones, whose aim is to help refugees. Among them one can mention, e.g., the United Nations, Red Cross, Red Crescent, etc. Non-governmental organizations are entities that are independent of public administration and their activity is not for profit. They operate in the form of associations or foundations. They are registered in the Special Registers, from which one can find out basic information about an organization's management board or its foundation date. Informal groups are groups of people who share a common goal, acting for specific people. Such organizations arise quite spontaneously, often in response to a specific problem or socio-political situation. Informal initiatives are not registered. In fact, non-governmental organizations play a key role in helping migrants, refugees. NGOs provide foreigners with psychological, legal and translation assistance, organize language courses, and integration activities. International organization which support refugees in these areas are for example: Syrian American Medical Society, Karam Foundation, Sunrise USA, Islamic Relief USA, Project Amal Ou Salaam. NGOs are coordinating and supporting refugees often with UN cooperation [https://www.huffingtonpost.com/yasmin-nouh/ syrian-refugee-relief-organizations_b_8142492.html; https://www.raptim.org/focus-on-ngos-27-organizations-that-help-refugees].

In addition, they conduct advocacy activities; try to bring about changes in the law to improve the situation of some groups. They, for example, monitor the applicable law and its application by the central and local government administration. Such organizations are often a first aid point for refugees. For foreigners going to another country can be difficult. NGOs help newcomers find the services they need to successfully integrate. These institutions provide, e.g., mental health services or help to find a job or an apartment. They also organize projects and meetings in refugee centers. Organizations should, in principle, complement the activities of the government administration. In practice, however, many of the duties, that fall under the responsibility of the government, rest with the third 
sector. Unfortunately, despite the activities that are necessary to provide refugees with a minimal sense of security, the organizations themselves do not get virtually any help from the state.

\section{CONCLUSIONS}

The article dealt with the way in which the Western world provides help to refugees. It is a very important problem in international law. Sometimes international law obligation is not enough to convince society that accepting refugees is a right and good decision. In the paper there were presented institutions which serve help for refugees, as well as the ways in which countries and organizations use legislation tools. It should be emphasized that the Western countries do a lot as far as providing help for refugees is concerned. This can be noticed when taking into account, e.g., the part of UN budget earmarked for helping refugees. It is very important that international community is trying to do a lot for people who suffer and need help which is commendable from the humanitarian point of view. Some countries, however, refuse to help for fear of the breach of internal security and possible economic problems.

Tytul: Uchodźcy, migranci i bezpaństwowcy w prawie międzynarodowym - przegląd aktów prawnych

Streszczenie: Artykuł podejmuje próbę ukazania problemu uchodźców i osób migrujących między krajami, jako bardzo ważny aspekt prawa międzynarodowego. Problem, który może generować zyski i straty dla zaangażowanych krajów w wielu obszarach. Razem z napływem osób z zagranicy początkowo rosną wydatki związane z procesem administracyjnym, ale rośnie również potencjalny kapitał ludzki. Zależy to od polityki danego kraju, czy potrafi wykorzystać taki potencjalny kapitał. Czasami zobowiązanie wynikające z prawa międzynarodowego nie wystarcza, aby przekonać społeczeństwo, że przyjmowanie uchodźców jest słuszne. Migracja jest niejako naturalnym procesem występującym pomiędzy krajami. Jest ona generowana różnymi czynnikami. Prawo międzynarodowe pozwala ją uporządkować i sklasyfikować tak, aby jednostki, które we własnym kraju napotykają poważne problemy, mogły spróbować żyć gdzie indziej.

Słowa kluczowe: uchodźcy, prawo międzynarodowe, migracja, organizacje międzynarodowe, ONZ 


\section{REFERENCES}

\section{Literature}

1. Dyl, M., et al., 2011, Podmioty administrujące. System Prawa Administracyjnego, C.H. Beck, Warszawa.

2. Goodwin-Gill, G., McAdam, J., 2007, The Refugee in International Law, $3^{\text {rd }}$ ed., Oxford University Press, Oxford.

3. Grahl-Madsen, A., 1972, The Status of Refugees in International Law. Volume II: Asylum, Entry and Sojourn, "International Affairs", 49 (3).

4. Kowalczyk, B., 2014, Polski system azylowy, Wydawnictwo UW, Wrocław.

5. Peers, S., 2011, EU Justice and Home Affairs Law, $3^{\text {rd }}$ ed., Oxford University Press, New York.

6. Pietraś, M., (red.), 2002, Oblicza procesów globalizacji, Wydawnictwo UMCS, Lublin.

7. Pietraś, M. (red.), 2006, Międzynarodowe stosunki polityczne, Wydawnictwo UMCS, Lublin.

8. Podraza, A., 2014, Integracja europejska w czasach kryzysu: scenariusz rozwoju Unii Europejskiej w XXI wieku, [in:] M. Pietraś, H. Dumała, B. Surmacz, A. Ziętek (red.), Teoria i praktyka stosunków międzynarodowych. Dziedzictwo intelektualne Profesora Ziemowita Jacka Pietrasia, Wydawnictwo UMCS, Lublin.

9. Robinson, N., 1953, Convention Relating to the Status of Refugees, Its History, Contents and Interpretation, Institute of Jewish Affairs, New York.

10. Tosiek, P., 2014, Dynamika kryzysu Unii Europejskiej, [in:] M. Pietraś, H. Dumała, B. Surmacz, A. Ziętek (red.), Teoria i praktyka stosunków międzynarodowych. Dziedzictwo intelektualne Profesora Ziemowita Jacka Pietrasia, Wydawnictwo UMCS, Lublin.

11. Weis, P., 1995, The Travaux Préparatoires Analysed with a Commentary, Cambridge University Press, Cambridge.

Internet sources

1. http://popstats.unhcr.org/en/overview (access: 03.01.2018).

2. http://www.ijrcenter.org/refugee-law/ (access: 03.01.2018).

3. http://www.unhcr.org/en-us/news/latest/2016/3/56e95c676/refugees-migrants-frequently-asked -questions-faqs.html (access: 03.01.2018).

4. http://www.unhcr.org/figures-at-a-glance.html (access: 03.01.2018).

5. http://www.un.org/en/index.html (access: 03.01.2018).

6. http://www.unhcr.org/non-governmental-organizations.html (access: 03.01.2018).

7. https://www.coe.int/en/web/portal/-/council-of-europe-action-plan-on-protecting-refugee-and -migrant-children-and-high-level-meetings (access: 03.01.2018).

8. https://www.huffingtonpost.com/yasmin-nouh/syrian-refugee-relief-organizations_b_8142492. html (access: 03.01.2018).

9. https://www.raptim.org/focus-on-ngos-27-organizations-that-help-refugees/ (access: 03.01.2018).

10. https://www.icrc.org/eng/war-and-law/treaties-customary-law/geneva-conventions/overviewgeneva-conventions.htm (access: 03.01.2018).

11. http://mordi.mydevil.net/portalzk/baza_wiedzy/artykuly/DM_ZK.pdf (access: 04.06.2018). 


\section{Legal acts}

1. Consolidated version of the Treaty on the Functioning of the European Union,https://eur-lex. europa.eu/legal-content/EN/TXT/?uri=celex\%3A12012E\%2FTXT (access: 06.07.2018).

2. Geneva Convention Relative to The Protection of Civilian Persons in time of War of 12 August 1949 part III Status and Treatment of Protected Persons, section II - Aliens in the Territory of a Party to the Conflict Article 44 VII. "Refugees".

3. Official Journal of the European Union. Directive 2003/54/EC of the European Parliament and of the Council. European Union, Brussels 2003.

4. The 1948 Universal Declaration of Human Rights (access: 05.07.2018).

5. The 1951 United Nations Convention Relating to the Status of Refugees (access: 05.07.2018).

6. The 1966 Bangkok Principles on Status and Treatment of Refugees [10] adopted at the Asian -African Legal Consultative Committee in 1966 (access: 05.07.2018).

7. The 1967 Protocol Relating to the Status of Refugees (access: 05.07.2018).

8. The 1967 UN General Assembly Declaration on Territorial Asylum (access: 05.07.2018).

9. The 1969 OAU Convention Governing the Specific Aspects of Refugee Problems in Africa (access: 05.07.2018).

10. The 1974 United Nations Declaration on the Protection of Women and Children in Emergency and Armed Conflict (access: 05.07.2018).

11. The 1976 Council of Europe's Recommendation 773 (1976) on the Situation of de facto Refugees (access: 05.07.2018).

12. The 1984 Cartagena Declaration on Refugees for Latin America and its three successors (access: 05.07.2018).

13. The 1989 Convention on the Rights of the Child (access: 05.07.2018).

14. The 1998 Conclusion on International Protection by the Executive Committee of the High Commissioner's Programme (access: 05.07.2018).

15. The 2001 Declaration by States Parties to the 1951 Convention and/or its 1967 Protocol Relating to the Status of Refugees (access: 05.07.2018).

16. The 2004 European Union's Council Directive on minimum standards for the qualification and status of third country nationals and stateless persons as refugees or as persons who otherwise need international protection (access: 05.07.2018).

17. The 2016 New York Declaration for Refugees and Migrants (access: 05.07.2018).

18. Treaty establishing the European Community (Nice consolidated version) (Official Journal C 325, 24/12/2002, PP. 0033-0184, Official Journal C 340, 10/11/1997 P. 0173 - Consolidated version), https://eur-lex.europa.eu/legal-content/EN/TXT/?uri=CELEX\%3A12002E\%2FTXT (access: 06.07.2018). 